\title{
Forkhead Box Protein P3 Staining Method
}

National Cancer Institute

\section{Source}

National Cancer Institute. Forkhead Box Protein P3 Staining Method. NCI Thesaurus.

Code C122847.

An immunohistochemical technique used to detect the presence of forkhead box protein P3 in a tissue sample. 